\title{
Integrated Pest Management in Portugal: from Policies to Practices
}

\author{
Cristina Amaro da $\operatorname{Costa}^{1}$, Maria do Céu Godinho ${ }^{2}$, José Lima Santos ${ }^{3}$, António Mexia ${ }^{4}$, \\ Pedro Amaro ${ }^{5}$
}

\author{
${ }^{1}$ Escola Superior Agrária/Instituto Politécnico de Viseu, 3500-606 Viseu, Portugal \\ E-mail: amarocosta@esav.ipv.pt \\ ${ }^{2}$ Escola Superior Agrária/Instituto Politécnico de Santarém, Quinta do Galinheiro - S. Pedro, 2001-904 Santarém, Portugal; \\ E-mail: mariac.godinho@gmail.com \\ ${ }^{3}$ Instituto Superior de Agronomia/Universidade de Lisboa, 1349-017 Lisboa, Portugal, \\ E-mail: jlsantos@isa.ulisboa.pt \\ ${ }^{4}$ Instituto Superior de Agronomia/Universidade de Lisboa, 1349-017 Lisboa, Portugal, \\ E-mail: amexia@isa.ulisboa.pt \\ ${ }^{5}$ Instituto Superior de Agronomia/Universidade de Lisboa, 1349-017 Lisboa, Portugal
}

\begin{abstract}
Integrated pest management is an ecosystem approach to crop protection that combines different control methods to reduce pesticide use and to obtain safe food products with lower environmental impact. It has increased in Europe and since 2014, it is mandatory for farmers as a basis for their crop protection strategy.

Using the Portuguese context as a case study, the evolution of integrated pest management adoption is analyzed. Country statistics and survey-based data are used to highlight technical differences among farmers, their motivations and attitudes that give rise to environmental benefits and food safety. A survey was applied to vineyards and apple and pear orchards in integrated pest management and in organic and conventional farming. The collected data were related with farmer profile, farm description, farmers' motivations towards sustainable farming practices, technical itinerary and practices related to pesticide use. A total of 177 questionnaires were applied.

Integrated pest management farmers are motivated to adopt biological, biotechnical and cultural solution, even if more expensive, and to give up toxic pesticides, to reduce agricultural impacts, while producing healthier and safer products. Practices that affect crop protection and soil conservation varied between agricultural systems, and can be used as lessons to improve their quality.
\end{abstract}

Keywords - farmers' attitudes, indicators, motivations, sustainable farming practices.

\section{INTRODUCTION}

Agriculture plays a key role in producing ecosystem services, such as farmland biodiversity, water and soil quality, climate stability or landscape maintenance. Simultaneously, many farming practices lead to soil depletion, water shortages, pollution and loss of wildlife habitats and biodiversity [1,2].

In the last two decades, the use of pesticides has decreased in European countries including Portugal $[3,4]$. However, it is still responsible for health risks and impacts on the environment. In 2011, $1.9 \%$ of total food samples analyzed in Europe exceeded the legal Maximum Residue Levels (MRL), while in Portugal that percentage rose to $3.1 \%$ of collected food samples $(4.9 \%$ in fruits and nuts and $2.8 \%$ in vegetables) [4,5]. Intoxications caused by misuse or accidental exposure, and also by oral ingestion (voluntary or not) of organophosphorus compounds and herbicides were reported [6,7].

The reduction of the negative effects of intensive agriculture and pesticide use has been one of the major concerns of European policies [1,8]. Therefore, agrienvironment programs were introduced in the European agricultural policy in 1985 to encourage EU farmers to adopt agricultural production methods compatible with the preservation of the environment and natural resources. The agri-environmental support aimed to promote the transformation of conventional agriculture (CA) by encouraging the adoption of IPM and organic farming (OF). These systems endorse and ensure long term adoption of practices compatible with environmental protection and food production with equivalent quality and yields [9]. This support should compensate farmers for using environmentally beneficial, but more expensive, farming techniques.

In 1992, the application of the agri-environment programs was compulsory for member states in the framework of 
their rural development plans, whereas they remained optional for farmers. In fact, until 2014, agri-environment payments were implemented on a voluntary basis through contracts that established a set of commitments that the beneficiary was required to fulfill, including fertilizer reduction, pesticide reduction, extensification of livestock farming, crop rotation, maintenance of set-aside areas, prevention or reduction of soil erosion, use of local genetic resources, biodiversity conservation, upkeep of the landscape, water-related actions, buffer strips, field margins, and wetland management [8].

Since 2000, an increasing number of farmers have adopted environmental farm management practices, such as IPM or OF, in response to incentives provided through government payments and regulations, and voluntary private-led initiatives, often promoted by food processors and retailers, local markets or by individual farmers [2,10]. More than 22.2 billion euro in EU funds were allocated to encourage farmers to protect and enhance the environment on their farmland $[1,11]$.

Thus, the evaluation of the agri-environmental policies and programs is crucial in order to determine if the cost of paying additional best practices was compensated by the environmental benefits generated [12,13]. In 2000, results from the first agri-environmental measures demonstrated that the programs have had little effect in reducing intensive practices, but in 2011, evidence proved that the conversion to friendly farming systems was effective in achieving their environmental benefits, especially in the case of IPM and OF [8,11].

Unfortunately, only a third to a half of OECD member countries is regularly monitoring these environmental benefits [2]. Primdahl et al. [13] found that half of the farming systems monitored were assessed based on general beliefs, rather than on objective evidence, of how agricultural practices are linked to environmental alterations and protection of resources and biodiversity. Only $15 \%$ were based on quantitative models that provide a statistical prediction of how changes in agricultural practices will have specific environmental impacts. Nevertheless, a survey conducted in 2005 to 62 international IPM projects covering 26 countries revealed that in over $60 \%$ of the projects pesticide use was reduced by $60 \%$, on average, indicating a broad impact of IPM [14].

In Portugal, the agri-environmental policies have supported IPM through rural development measures; in 1999, 55486 ha were under this production system and in 2013, the area was five times larger (248 595 ha). The total area and the number of farmers, the public investment and status given to IPM in the present European policies, especially in Directive 2009/128/EC of the European Parliament and of the Council of 21 October
2009 that establishes a framework for Community action to achieve the sustainable use of pesticides, justify the analysis of the technical, environmental and economic benefits of IPM.

Establishing a framework of relationships between the agri-environmental measures and environmental pressures is required to assess the extent to which agrienvironmental objectives were achieved. This can be done using test plots, case studies, quantified impact models, and surveys [8,13], as they define suitable environmental indicators (a metric or a set of metrics that helps provide insight into the linkages between agricultural activities and environmental impacts). These indicators will provide information to monitor and analyze the effects of those policies on the environment and to enhance the understanding, and study the effects, of possible policy scenarios and agricultural projections [15].

The purpose of the present paper is to understand if agrienvironment support and IPM adoption truly lead to the positive environmental impact that is expected with the adoption of environmentally friendly farming practices and with the sustainable use of pesticides. More specifically, this paper seeks to determine which environmentally friendly farming practices and motivations towards the adoption of sustainable farming practices are adopted by IPM farmers, and how farmers motivations and attitudes are related to technical options. The identification of the technical operations and tasks related to the environmentally friendly farming practices in IPM and the recognition of the technical differences among farmers that help promote environmental benefits and food safety are also pertinent aims of this study.

In the present study, the evolution of IPM is described, based on country statistics. Additionally, survey-based data are analyzed to support the definition of the farmer profile, farm description, motivations towards sustainable farming practices, technical profile and practices related to pesticide use associated with IPM strategies, by comparing it with $\mathrm{CA}$ and $\mathrm{OF}$.

\section{IPM - from the past to the present}

2.1 IPM and environment policies in the period of 1994-2013

IPM began in Portugal based on the European policy supported by the Council Regulation (EEC) No 2078/92 of 30 June 1992 and evolved into 3 phases: (1) Agrienvironment Program, 1994 to 1999; (2) RURIS, 2000 to 2006; (3) PRODER, 2007 to 2013.

In 1994, IPM was regulated with national laws and the Agri-environment Program started, on an annual basis, for farmers who were willing to adopt best agricultural practices during at least 5 years. The major aim was to 
encourage farmers' adoption of environmentally friendly farming techniques compatible with the increasing need for natural resources protection and the upkeep of the landscape and the countryside. Within five years, the program was successful, confirmed by a large number of IPM experts (220), farmers (9 359) and IPM associations (48) and there was a significant agricultural area under IPM systems (62 831 ha) [16].

Based on the Council Regulation (EC) No 1257/1999 of 17 May, the national rural development plan was established (RURIS) and reinforced the importance of local and traditional agricultural systems. Thus, it seemed crucial to support IPM and OF for a large number of crops and to include other measures, namely pesticide risk reduction in water, minimum and zero tillage and the use of cover crops [16,17].

Finally, during the 2007-2013 period, a new rural development program - ProDer - was established, whose major goal consisted in sponsoring agriculture based on economic and sustainable principles. This program has reintroduced financial tools to encourage alternative production methods with economic and social concern for the sustainability of rural areas and the conservation of natural resources [18].

\subsection{IPM in Portugal from 1994 to 2013}

In 1995, the first financial protocols with farmers were established. In the first year (1996), the IPM area achieved 7236 ha and 927 farmers. At the end of the first agri-environment program (1999), IPM was adopted by 7 450 farmers on 55486 ha, mainly on orchards and vineyards (tables 1 and 2). The IPM area was spread over three main regions: 'Norte', 'Lisboa e Vale do Tejo' and 'Alentejo', respectively with $38 \%, 27 \%$ and $18 \%$ of the total area. IPM in orchards was allocated mostly in 'Lisboa e Vale do Tejo' (45\%) and in vineyards in the 'Norte' region (44\%) [16,19].

In 2005, the IPM area increased to 179840 ha and 19753 farmers, especially in vineyards $(52 \%)$, olive $(25 \%)$ and apple orchards (14\%) (tables 1 and 2). About 11233 ha were in the 'Norte' region with $37 \%$ of vineyards supported area in this region. In 'Alentejo', the production area was 57103 ha (32\% of total area) with 2 719 farmers. In 2013, PRODER contributed to a major development of the IPM production area, and reached 248 595 ha and 6692 farmers, with greater adoption in 'Alentejo' (62\%). This increase was due to the development of IPM in new crops, in particular pastures (table 2). At this time, IPM was also adopted on 35553 ha of vineyards and 17821 ha of orchards.

Despite the positive evolution of the IPM area from 2005 (RURIS) to 2013 (PRODER), the number of farmers did not reach the target set for this period (the PRODER target set for the 2007-2013 period was 24000 farmers). The average area per farm was higher in 2013, compared with the previous years (table 1), mostly because farmers were required to practice IPM across the entire farm in order to get financial support [12]. This new condition has discouraged less capacitated farmers, and led to an IPM area concentration and to a reduction in the number of farmers between 2011 and 2013.

Table 1: Area, number of farmers and average farm size in IPM in Portugal [10,12,20-22]

\begin{tabular}{|c|c|c|c|c|}
\hline \multirow{2}{*}{ Region } & \multicolumn{4}{|c|}{ Area (ha) } \\
\hline & 1999 & 2005 & 2011 & 2013 \\
\hline \multirow[t]{2}{*}{ Norte } & 21 & 66 & 41 & 41 \\
\hline & 251 & 447 & 630 & 820 \\
\hline \multirow[t]{2}{*}{ Centro } & 6888 & 18 & 22 & 21 \\
\hline & & 091 & 150 & 382 \\
\hline Lisboa e Vale do & 15 & 34 & 28 & 27 \\
\hline Tejo' & 112 & 248 & 100 & 701 \\
\hline \multirow[t]{2}{*}{ Alentejo } & 10 & 57 & 155 & 153 \\
\hline & 149 & 103 & 387 & 820 \\
\hline Algarve & 2086 & 3951 & 4074 & 3872 \\
\hline \multirow[t]{3}{*}{ Total } & 55486 & 179 & 251 & 248 \\
\hline & & 840 & 341 & 595 \\
\hline & \multicolumn{4}{|c|}{ Farmers (number) } \\
\hline Norte & 3560 & 11 & 3536 & \\
\hline & & 233 & & 3378 \\
\hline Centro & 1055 & 2778 & 1072 & 1028 \\
\hline $\begin{array}{c}\text { Lisboa e Vale do } \\
\text { Tejo }\end{array}$ & 1894 & 2680 & 858 & 824 \\
\hline Alentejo & 778 & 2719 & 1215 & 1232 \\
\hline Algarve & 163 & 343 & 227 & 230 \\
\hline \multirow[t]{2}{*}{ Total } & 7450 & 19753 & 6908 & 6692 \\
\hline & \multicolumn{4}{|c|}{ Farm size (ha) } \\
\hline Norte & 6,0 & 5,9 & 11,8 & 12,4 \\
\hline Centro & 6,5 & 6,5 & 20,7 & 20,8 \\
\hline $\begin{array}{c}\text { Lisboa e Vale do } \\
\text { Tejo' }\end{array}$ & 8,0 & 12,8 & 32,8 & 33,6 \\
\hline Alentejo & 13,0 & 21,0 & 127,9 & 124,9 \\
\hline Algarve & 12,8 & 11,5 & 17,9 & 16,8 \\
\hline Total & 9,3 & 11,5 & 36,4 & 37,1 \\
\hline
\end{tabular}

Table 2: Area of IPM crops in Portugal (ha)[20-22]

\begin{tabular}{l|r|r|r}
\hline Crop & $\mathbf{1 9 9 9}$ & $\mathbf{2 0 1 1}$ & $\mathbf{2 0 1 3}$ \\
\hline Permanent crops & & & \\
& 13 & & 17281 \\
& 339 & 17418 & \\
\hline $\begin{array}{l}\text { Fresh fruits orchards } \\
\text { Dry fruits and olive } \\
\text { orchards }\end{array}$ & & 43329 \\
\hline $\begin{array}{l}\text { Vineyards } \\
\text { Ving }\end{array}$ & 42 & 34543 & 35553 \\
\hline
\end{tabular}




\begin{tabular}{l|r|r|r}
\hline & 146 & & \\
\hline Rice & & 17601 & 18456 \\
\hline $\begin{array}{c}\text { Forage and non- } \\
\text { permanent crops }\end{array}$ & & 25536 & 27863 \\
\hline Vegetables & 1 & 1117 & 1168 \\
\hline & & 102 & 104945 \\
& & 962 & \\
\hline Permanent pastures & 55 & 251 & 248 \\
\hline & 486 & 339 & 595 \\
\hline
\end{tabular}

farmer profile (socio-economic characterization), farm description, motivations towards sustainable farming practices, technical profile (inventory of farming practices) and crop protection practices.

\subsection{Data analysis}

Results from the survey were stored in a database, and categorical variables were codified as numbers ( 0 or 1 ) so that an exploratory analysis could be performed to identify which variables were related to the production system (IPM, OF or CA) or to each other. The main

Technical support was fundamental for the adoption of IPM, particularly in the beginning of the program. In 1995, the government recognized the first IPM farmer associations. In 1998, about 28 farmer associations were recognized as IPM support structures operating mostly in vineyards and orchards, and this number continued to increase: 66 organizations in 2000, 112 organizations in 2004 and 162 organizations in 2013 [16,19,23].

The requirements for agri-environment payments in Portugal between 1995 and 2013 were mainly administrative actions undertaken by farmers: have a farm management plan, use only authorized pesticides, have a field book, keep the evidence of pesticides purchased and of the soil, water and plant material analysis, have a shelter for pesticides and fertilizers [16].

\section{IPM. ANALYSIS OF FARMERS' MOTIVATIONS AND IPM TECHNICAL AND PESTICIDE USE PROFILES}

\subsection{Methodology}

The IPM adoption in Portugal was characterized based on survey-based data collected from IPM, OF and CA farms in the most important regions and crops where pesticide use is of more concern: vineyards - Alentejo, Dão, Douro, Verdes - and apple and pear orchards - Dão, Oeste. The questionnaire was conducted between 2007 and 2009 by trained technicians working at different farmers associations, to the person responsible for the decisions at farm level. The questionnaires were applied face-to-face and a total of 177 survey questionnaires, conducted in different farms, were considered valid (13 OF farms, 91 IPM farms, 73 CA farms).

These crops were chosen based on different criteria. Firstly, vineyard was selected because it is the crop that is responsible for the largest amount of pesticides used in Portugal, mainly fungicides [3,24]. Apple and pear orchards were selected based on the fact that the key insect pests and diseases are numerous, causing serious problems to farmers, and on account of apples and pears being among the food products with the highest percentage of samples with pesticide residues above legal limits [5]. The questionnaires included data related to the variables suggesting relations with IPM, OF and CA production systems were identified with a Principal Component Analysis. As this analysis was extensive [25], only the variables that explained significant levels of variance were included in the present study.

An analysis of variance (one-way ANOVA) was used to detect differences among production systems (OF, IPM and CA), in order to better understand and profile each group of variables (farmer profile, farm description, motivations towards sustainable farming practices, technical profile and practices related to pesticide use). Means were then compared using the Tukey HSD tests and Bonferroni-Holm, whether the homogeneity of variances was observed or not. Values of $\mathrm{P} \leq 0.05$ were considered significant. All statistical analyses were carried out using IBM SPSS Statistics for Windows, Version 22.0 (Armonk, NY: IBM Corp.).

\section{RESULTS}

\subsection{Farmer profile}

Based on the survey results, the average farmer was 53 years old, men older (57 years average) than women (49 years average), and orchard producers older than vineyard producers. IPM and OF farmers were significantly younger than $\mathrm{CA}$ (table 3 ).

The surveyed farmers had on average a secondary level of education (ISCED 2-3), which reveals that these farmers have an education level well above the Portuguese national average in Portugal (on average, farmers have basic education and $88 \%$ have only practical agricultural training) [26]. This education level was higher in $\mathrm{OF}$ and IPM farmers, as $60 \%$ of farmers had secondary or higher education. More than half of CA farmers had less than six years of education (ISCED 0-2) ${ }^{1}$ (table 3). Most IPM

\footnotetext{
${ }^{1}$ The International Standard Classification of Education (ISCED) was developed by UNESCO and adopted since 1997 to facilitate comparisons of education statistics and indicators across countries on the basis of uniform and internationally agreed definitions [27]. Until 2011 ISCED had 7 levels of education, from early childhood education (ISCED 0), primary education (ISCED 1), secondary education (ISCED 2-3), post-secondary non tertiary education (ISCED 4) to tertiary education levels (ISCED 5-6).
} 
(93\%) and OF (77\%) farmers had already participated in training courses related to IPM, pesticide use, and general agricultural training.

Table 3: Average values of variables related with farmer profile of IPM, OF and CA farmers

\begin{tabular}{lccc}
\hline \multicolumn{1}{c}{ VARIABLE } & $\begin{array}{c}\text { OF } \\
(\mathrm{n}=13)\end{array}$ & $\begin{array}{c}\text { IPM } \\
(\mathrm{n}=91)\end{array}$ & $\begin{array}{c}\mathrm{CA} \\
(\mathrm{n}=73)\end{array}$ \\
\hline age & $48^{\mathrm{a}}$ & $51^{\mathrm{a}}$ & $62^{\mathrm{b}}$ \\
\hline education level (ISCED) $^{1}$ & $2.54^{\mathrm{a}}$ & $1.956^{\mathrm{b}}$ & $1.356^{\mathrm{c}}$ \\
\hline $\begin{array}{l}\text { participation in training } \\
\text { courses (\%) }\end{array}$ & $77^{\mathrm{a}}$ & $93^{\mathrm{a}}$ & $33^{\mathrm{b}}$ \\
\hline other economic activities (\%) & 77 & $53^{\mathrm{a}}$ & $44^{\mathrm{b}}$ \\
\hline
\end{tabular}

Note: ${ }^{a, b, c}$ Scores in the same row with a the same superscript are significantly different at $\mathrm{p}<.05$ (post hoc Bonferroni-Holm and Tukey multiple comparison tests)

Almost 50\% of the inquired farmers have other economic activities meaning that a part of their income is obtained outside of the farm, and that they are not fully dedicated to farming. This figure is in line with the Portuguese reality $(51 \%$ of farmers work less than $50 \%$ of a full-time equivalent and dedicate, on average, 22 hours/week of labor to their farms) $[28,29]$. This is especially relevant among OF farmers, wherein more than three quarters have other jobs in addition to agriculture (77\%) (table 3 ).

\subsection{Farm description}

Farms included in this study have an average area of 30.9 ha, when compared to the national average farm size (12 ha of utilized agricultural area per farm) [29], and OF and IPM farms are larger than CA ones -46.2 and 37.6 ha in average, respectively. More than $80 \%$ of the farms are held by individual farmers while only $20 \%$ work as a company (enterprises), which is higher when compared to the national figure $(27 \%$ of the Utilized Agricultural Area) $[1,29]$, probably because vineyard and orchard farms are more professionalized. The average number of workers per farm is higher in IPM (10.2workers), with twice more workers, on average, than in CA farms (4.64.0 workers) (table 4). Comparing the number of permanent hired workers on these farms, we observe that number of permanent hired workers outweigh the Portuguese national average (far less than 1 per farm) $[28,30]$.

Table 4: Average values of variables related with IPM, $O F$ and $C A$ farm characteristics

\begin{tabular}{lccc}
\hline VARIABLE & $\begin{array}{c}\text { OF } \\
(\mathrm{n}=13)\end{array}$ & $\begin{array}{c}\text { IPM } \\
(\mathrm{n}=91)\end{array}$ & $\begin{array}{c}\mathrm{CA} \\
(\mathrm{n}=73)\end{array}$ \\
\hline farm dimension (ha) & $59.75^{\mathrm{a}}$ & $44,50^{\mathrm{a}, \mathrm{b}}$ & $10.47^{\mathrm{b}}$ \\
\hline number of workers & $7.7^{\mathrm{a}}$ & $10.2^{\mathrm{b}}$ & $4.6^{\mathrm{c}}$ \\
\hline
\end{tabular}

Note: ${ }^{a, b, c}$ Scores in the same row with a the same superscript are significantly different at $p<.05$ (post hoc Bonferroni-Holm and Tukey multiple comparison tests)

4.3. Motivations towards sustainable farming practices Various recent studies demonstrated that the motivations towards a particular production system go far beyond technical and economic issues [31,32]. Cultural, social and environmental beliefs underlie the choice of more sustainable production systems, such as IPM or OF. In fact, we found that some agricultural practices regarded attitudes or reasons pertaining to more sustainable practices (almost $54 \%$ of variance is explained by the two first axes) (table 5).

Forward selection results, from the principal component analysis, showed that the variables 'look for a biological, biotechnical, cultural solution' ( $\mathrm{F}=18.36$; $\mathrm{p}=0.002)$, 'look for a new pesticide' $(\mathrm{F}=21.13 ; \mathrm{p}=0.002)$, 'not change agricultural practices in favor of species conservation' $(\mathrm{F}=4.58 ; \mathrm{p}=0.008)$, and 'give up toxic pesticides, using them only when needed, to preserve local fishes' ( $\mathrm{F}=2.79$; $\mathrm{p}=0.044$ ), were significant for $\mathrm{p}<0.05$. The variable 'look for a biological, biotechnical, cultural solution' was responsible for $14.0 \%$ of variance and the variable 'look for a new pesticide' for $18 \%$ of variance. The variables 'use an expensive crop protection solution' and 'not use an expensive crop protection solution' were also significant for $\mathrm{p}<0.10$.

Table 5: Principal Component analysis of the OF, IPM and CA farmers motivations towards the adoption of sustainable farming practices

\begin{tabular}{|c|c|c|c|c|}
\hline \multirow{2}{*}{ Question } & \multirow{2}{*}{ Answer/variable } & \multicolumn{3}{|c|}{ Conditional Effects } \\
\hline & & $\lambda$ & $\mathbf{p}$ & $\mathbf{F}$ \\
\hline $\begin{array}{l}\text { If it were necessary } \\
\text { to reduce pesticide } \\
\text { use, with economic } \\
\text { risk to your farm, }\end{array}$ & $\begin{array}{l}\text { change agricultural } \\
\text { practices in favour } \\
\text { of species } \\
\text { conservation. }\end{array}$ & 0.01 & 0.262 & 1.36 \\
\hline $\begin{array}{l}\text { to save a very rare } \\
\text { butterfly that was } \\
\text { observed in the } \\
\text { area, you would: }\end{array}$ & $\begin{array}{l}\text { not change } \\
\text { agricultural practices } \\
\text { in favour of species } \\
\text { conservation. }\end{array}$ & 0.03 & $0.008 *$ & 4.58 \\
\hline $\begin{array}{l}\text { If near your farm, } \\
\text { all the fishes were } \\
\text { found dead as a } \\
\text { result of pesticide }\end{array}$ & $\begin{array}{l}\text { not use pesticides in } \\
\text { the next campaign, } \\
\text { to preserve local } \\
\text { fishes? }\end{array}$ & 0.00 & 0.372 & 1.19 \\
\hline \multirow[t]{2}{*}{ use, would you: } & $\begin{array}{l}\text { give up toxic } \\
\text { pesticides, using } \\
\text { them only when } \\
\text { needed, to preserve } \\
\text { local fishes? }\end{array}$ & 0.02 & $0.044 *$ & 2.79 \\
\hline & $\begin{array}{l}\text { buy pesticide } \\
\text { equipment that }\end{array}$ & 0.00 & 0.432 & 0.83 \\
\hline
\end{tabular}




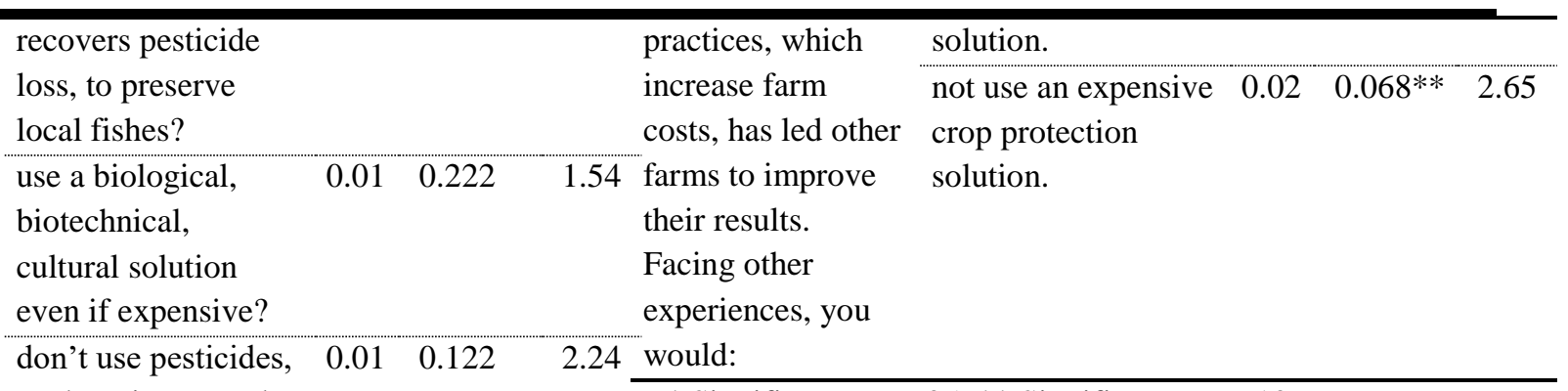

so there is no need

* Significant at $\mathrm{p}<.05 ; * *$ Significant at $\mathrm{p}<.10$

of change to

preserve local

fishes?

\begin{tabular}{lllll}
$\begin{array}{l}\text { If you had to } \\
\text { change your }\end{array}$ & $\begin{array}{l}\text { reduce pesticides for } \\
\text { a subsidy. }\end{array}$ & 0.01 & 0.202 & 1.47 \\
$\begin{array}{l}\text { agricultural } \\
\text { practices, by } \\
\text { government } \\
\text { decision, you }\end{array}$ & $\begin{array}{l}\text { reduce pesticides to } \\
\text { have technical }\end{array}$ & 0.01 & 0.280 & 1.18 \\
support. & $\begin{array}{l}\text { suld: } \\
\text { have already } \\
\text { reduced the use of } \\
\text { pesticides. }\end{array}$ & 0.02 & 0.140 & 1.86 \\
& & & & \\
\hline
\end{tabular}

$\begin{array}{lllll}\text { In Portugal, about } & \text { give up pesticides to } & 0.02 & 0.224 & 1.49\end{array}$

2100 pesticide reduce poisoning

poisoning cases even $2 \%$.

$\begin{array}{lllll}\text { occur per year, and } & \text { give up pesticides to } & 0.00 & 0.636 & 0.44\end{array}$

of those $360 \quad$ reduce poisoning

happen with $\quad 50 \%$.

children less than 5 give up pesticides to $0.00 \quad 0.600 \quad 0.50$

years old. If

reduce poisoning

decreasing the use $100 \%$.

of toxic pesticides

would contribute

$\begin{array}{llll}\text { not give up } & 0.01 & 0.340 & 1.15\end{array}$

to reducing this

risk, you would:

pesticides, because it

Based on the biplot analysis, it is possible to identify some relations between the adopted farming system and the attitudes or reasons for embracing sustainable practices (figure 1).

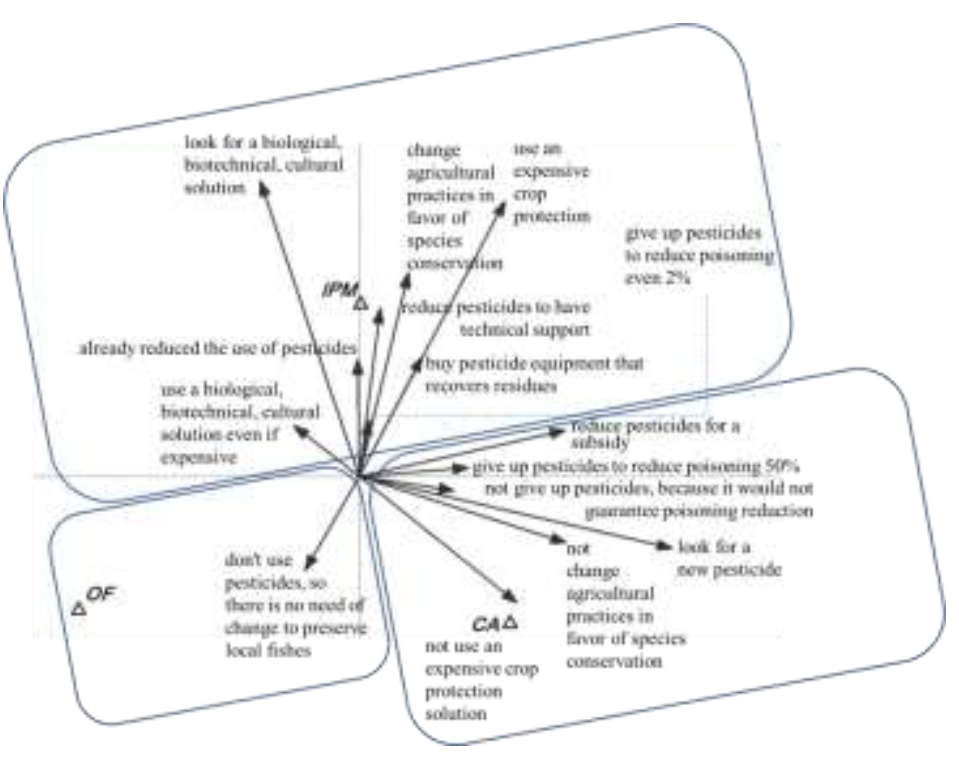

would not guarantee

poisoning reduction.

\begin{tabular}{|c|c|c|c|c|}
\hline $\begin{array}{l}\text { Facing a new or a } \\
\text { resistant pest or }\end{array}$ & $\begin{array}{l}\text { look for a new } \\
\text { pesticide. }\end{array}$ & 0.18 & $0.002 *$ & 21.13 \\
\hline $\begin{array}{l}\text { disease, or even in } \\
\text { the presence of } \\
\text { new technical }\end{array}$ & $\begin{array}{l}\text { look for a biological, } \\
\text { biotechnical, } \\
\text { cultural solution. }\end{array}$ & 0.14 & $0.002 *$ & 18.36 \\
\hline $\begin{array}{l}\text { knowledge, you } \\
\text { would: }\end{array}$ & $\begin{array}{l}\text { use the same } \\
\text { solution. }\end{array}$ & 0.00 & 0.878 & 0.13 \\
\hline $\begin{array}{l}\text { In view of your } \\
\text { neighbour' farming }\end{array}$ & $\begin{array}{l}\text { use a new crop } \\
\text { protection solution. }\end{array}$ & 0.01 & 0.662 & 0.39 \\
\hline $\begin{array}{l}\text { success, with the } \\
\text { adoption of a new }\end{array}$ & $\begin{array}{l}\text { not use a new crop } \\
\text { protection solution. }\end{array}$ & 0.00 & 0.794 & 0.25 \\
\hline
\end{tabular}

Fig.1: Biplot for motivations towards the adoption of sustainable farming practices of $O F, I P M$ and $C A$ farmers

IPM farmers were ready to 'look for a biological, biotechnical, cultural solution', 'give up toxic pesticides, using them only when needed, to preserve local fishes' or to 'use an expensive crop protection solution'. Meanwhile, CA farmers will 'look for a new pesticide', 'will not change agricultural practices in favor of species conservation' and 'will not use an expensive crop protection solution'. The variable 'don't use pesticides, so there is no need of change to preserve local fishes' was positively related to OF farmers, but with no significance.

\subsection{Technical profile}

Concerning crop management, the results from our survey indicated that, compared to CA farmers, IPM and OF farmers use less 'tillage operations', adopt 'cover crops' (especially OF farmers), prefer 'organic fertilizations' 
instead of mineral ones, perform 'soil analysis' to decide their fertilization plans (especially IPM farmers) and frequently use 'green interventions' to control canopy environment. The adoption of these practices was significantly different among IPM and CA farmers, with the exception of tillage operations (table 6).

In 2010, in Portugal, the use of cover crops was adopted by $10 \%$ of farms, with more expression in the 'Norte' and 'Centro' regions and in orchards and vineyards and only $8 \%$ of farmers decided their fertilization plans based on soil analysis (8\%) [29,33]. IPM and OF farmers have exceeded these values, probably because they understand the contribution of such sustainable farming practices for the balance of the ecosystems, namely to improve functional biodiversity $[34,35]$.

Table 6: Percentage of sustainable practices (crop management and protection) adopted by IPM, OF and CA farmers

\begin{tabular}{lccc}
\hline VARIABLE $(\%)$ & OF & IPM & CA \\
& $(\mathrm{n}=13)$ & $(\mathrm{n}=91)$ & $(\mathrm{n}=73)$ \\
\hline
\end{tabular}

Technical profile - Practices related to crop management adopted by OF, IPM and CA farmers

\begin{tabular}{lccc}
\hline tillage & 62 & 67 & 78 \\
\hline cover crops & $77^{\mathrm{a}}$ & $38^{\mathrm{b}}$ & $11^{\mathrm{c}}$ \\
\hline organic fertilizations & $46^{\mathrm{a}}$ & $79^{\mathrm{b}}$ & $56^{\mathrm{a}}$ \\
\hline soil analysis & $77^{\mathrm{a}}$ & $82^{\mathrm{a}}$ & $7^{\mathrm{b}}$ \\
\hline green interventions & 62 & 66 & 42 \\
\hline
\end{tabular}

Pesticide use - Practices related to crop protection

\begin{tabular}{lccc}
\hline risk assessment & 92 & $99^{\mathrm{a}}$ & $85^{\mathrm{b}}$ \\
\hline $\begin{array}{l}\text { advice and national } \\
\text { advisory services }\end{array}$ & 46 & 78 & 44 \\
\hline \begin{tabular}{l} 
reading of labels \\
\hline $\begin{array}{l}\text { evaluation of pesticide } \\
\text { efficacy }\end{array}$
\end{tabular} & $59^{\mathrm{a}}$ & $85^{\mathrm{a}}$ & $97^{\mathrm{b}}$ \\
\hline $\begin{array}{l}\text { pesticide residues } \\
\text { analysis }\end{array}$ & 39 & 17 & 7 \\
\hline $\begin{array}{l}\text { use of protective } \\
\text { equipment }\end{array}$ & 85 & $95 \mathrm{a}$ & $85^{\mathrm{b}}$ \\
\hline $\begin{array}{l}\text { professional applicator } \\
\text { training }\end{array}$ & $46^{\mathrm{a}}$ & $45^{\mathrm{a}}$ & $7^{\mathrm{b}}$ \\
\hline
\end{tabular}

Note: ${ }^{a, b, c}$ Scores in the same row with a the same superscript are significantly different at $\mathrm{p}<.05$ (post hoc Bonferroni-Holm and Tukey multiple comparison tests)

\subsection{Pesticide use}

In Portugal, $71 \%$ of the total pesticides used are fungicides, with sulphur representing $90 \%$ of them (48\% of total pesticides, and especially in vineyards) [3]. Herbicides represent $14 \%$ of the total sales and insecticides only 2\%. From 2008 to 2011, the total pesticide sales decreased $18 \%$, especially due to a reduction in the use of sulphur, but $3.1 \%$ of total food samples analyzed in Portugal still exceeded the MRL [5]. According to our results, concerning the adoption of practices related to pesticide use, IPM farmers declared to use 'advice and national advisory services', practice 'risk assessment' for decision making, 'reading of labels' before pesticide treatment, 'evaluation of pesticide efficacy' regularly, request 'residues analysis' and 'use protective equipment', more often than $\mathrm{OF}$ and $\mathrm{CA}$ farmers (table 6).

The participation in 'professional applicator training' was similar between OF and IPM farmers. Differences between IPM and CA farmers were significant for 'risk assessment', 'evaluation of pesticide efficacy', 'use of protective equipment' and 'professional applicator training' (table 7).

\section{CONCLUSIONS}

Since 1990, the environmental performance of agriculture has improved in Europe based on agri-environment measures that were designed to protect and enhance the environment through the adoption of agricultural sustainable systems, such as IPM and OF $[1,8,11]$. These measures have been essential for the integration of environmental concerns by farmers and have originated a valuable contribution to the ecological balance of ecosystems.

Until 2014, IPM was adopted by farmers, on a voluntary basis, but since then, European states should promote IPM under the framework of their National Action Plans for the Sustainable Use of Pesticides.

Ultimately, farmers' actions and practices determine their environmental performance. Reacting to public concerns and policies, IPM farmers in general have become increasingly aware of the effects of their actions on the environment and have upgraded their management practices based on scientific and technical knowledge, and investments in environmentally friendly practices [2]. Based on the present case study, we can conclude that there are obvious differences between IPM and CA, related to farmer profile, farm description, motivations for IPM adoption, technical profile and practices related to pesticide use.

IPM farmers are younger, better educated, and more concerned with technical training. A significant number of IPM holdings are companies, specialized in one crop, with larger areas and employing more workers, both in orchards and vineyards, when compared to other systems. The results from our survey proved that IPM farmers are ready to look for biological, biotechnical and cultural solutions to control pests, are willing to give up toxic pesticides and to use more expensive crop protection 
solutions to preserve the environment and health. However, they usually want to be compensated with subsidies when they implement these sustainable agricultural practices.

Most IPM farmers are adopting cover crops to overcome weed problems and other technical issues (e.g. water, erosion), namely in permanent crops, such as orchards and vineyards. In fact, tillage, as a routine task, decreases from CA to IPM, and at the same time soil cover increases. Usually, IPM farmers execute green interventions to control the canopy environment (removal of side shoots, orientation of vegetation, among others). These techniques have several purposes: improve the canopy environment, reduce the number of fruits to improve size and quality, among others, and farmers don't receive any incentives to adopt them. IPM farmers also prefer organic fertilizations instead of mineral ones and organize their fertilization plans based on soil analysis.

IPM farmers are always more diligent in what pertains to pesticide use: risk assessment is the basis for decision making, advice from experts and national services is deemed indispensable, as well as information contained on labels, and they oversee the efficacy of pesticide treatments. These farmers are naturally apprehensive about the secondary effects of using pesticides and protect themselves with the appropriate equipment, more often than $\mathrm{OF}$ and CA farmers.

We might conclude that IPM, as a crop protection strategy, has been successful in Europe, and in particular in Portugal, in terms of area and number of farmers, due to the important technical support that was provided by farmers associations. Furthermore, the adoption of several sustainable practices, related to crop management and protection, and farmers' attitudes towards the use of pesticides are expected to have contributed to protecting, and enhancing, the environment and health safety. These variables (tables 3, 6 and 6) might be considered to establish new requirements for IPM support and used to monitor the environmental and health outcomes gained through this crop protection strategy and the sustainable use of pesticides.

The environmental and health outcomes that are obtained with these sustainable practices should be assessed, based on environmental indicators (simple metrics that disclose the linkages between agricultural activities and environmental impacts), as they will result in a balanced and sustainable management of resources and generate environmental services that have an economic value.

Some difficulties ensue when using these environmental indicators, as their monitoring (e.g. biodiversity or pesticide use) is challenging due to political, conceptual, practical (technical) and institutional factors [36], but it should be attempted. They will provide a coherent guidance for the best practices that should be defined as requirements for IPM while, at the same time, might be used in cost-benefit analysis of the most desirable policy measures and support programs, based on the identification and assessment of synergies between policy/program goals and their benefits [37].

The financial support of environmentally friendly farming systems, such as IPM, either by implementation of subsidies, by specific price policies or by ensuring a market for these specific products, should play a prominent role in supporting the sustainable development of rural areas and in responding to society's increasing demand for environmental services. It should further encourage farmers to serve society as a whole by introducing, or continuing to apply, agricultural production methods compatible with environmental and health protection, IPM being a prime example.

\section{ACKNOWLEDGEMENTS}

The authors wish to thank the growers, who kindly allowed us to conduct our work in their orchards and vineyards and APAS, AAPIM, PAINHO, AJAP, ADVID, AVITILIMA, APIDÃO, AGROBIO, ATEVA, SOGRAPE and BIOCOA for technical assistance. This work was financed by the AGRO 545 project "The environmental indicators to assess integrated pest management, integrated production, organic farming and the sustainable use of pesticides in Portugal".

\section{REFERENCES}

[1] EU, 2010, The CAP towards 2020: Meeting the Food, Natural Resources and Territorial Challenges of the Future., COM (2010) 672/5 final, COMISSÃO EUROPEIA, Bruxelas.

[2] OECD, 2008, Environmental Performance of Agriculture in OECD Countries since 1990, OECD, Paris.

[3] DGAV, 2014, Plano de Acção Nacional. Contexto Nacional Da Utilização de Produtos Fitofarmacêuticos., Ministério da Agricultura, do Mar, do Ambiente e do Ordenamento do Território, Lisboa.

[4] OECD, 2008, Environmental Performance of Agriculture in OECD Countries since 1990: Portugal., OECD, Paris.

[5] EFSA, 2013, "The 2010 European Report on Pesticide Residues in Food.," EFSA J., 11(3), p. 808 p.

[6] Cerejeira, M. J., Viana, P., Batista, S., Pereira, T., Silva, E., Valério, M. J., Silva, A., Ferreira, M., and Silva-Fernandes, A. M., 2003, "Pesticides in 
Portuguese Surface and Ground Waters," Water Res., 37(5), pp. 1055-1063.

[7] Teixeira, H., Proença, P., Alvarenga, M., Oliveira, M., Marques, E. P., and Vieira, D. N., 2004, "Pesticide Intoxications in the Centre of Portugal: Three Years Analysis," Forensic Sci. Int., 143(2), pp. 199-204.

[8] Court of Auditors, 2011, Is Agri-Environment Support Well Designed and Managed?, Publications Office of the European Union, Luxembourg.

[9] MADRP, 2005, Orientações Para Uma Estratégia de Desenvolvimento Rural. , ProDer/ Ministério do Desenvolviemnto Rural, da Agricultura, e das Pescas, Lisboa.

[10] AGROGES/GPP, 2009, Estudo de Avaliação Final (Ex-Post) Do Programa de Desenvolvimento Rural de Portugal Continental RURIS., AGROGES/GPP, Ministério da Agricultura, do Desenvolvimento Rural e das Pescas, Lisboa.

[11] EEA, 2005, Agriculture and Environment in EU-15 - The IRENA Indicator Report., Report No. 6/2005. European Environment Agency, Copenhagen.

[12] Domingos, T., Neves, A. O., Marta-Pedroso, C. (Ed. ., Martins, H., Vieira, R. S., Alves, M., Porta, M., and Ferreira, G., 2012, Relatório Final Da Avaliação Contínua Do Programa de Desenvolvimento Rural Do Continente 2007-2013 (ProDeR) Do Ano 2011., IST, IESE, IPB, Lisboa e Bragança.

[13] Primdahl, J., Vesterager, J. P., Finn, J. A., Vlahos, G., Kristensen, L., and Vejre, H., 2010, "Current Use of Impact Models for Agri-Environment Schemes and Potential for Improvements of Policy Design and Assessment," J. Environ. Manage., 91(6), pp. 1245-1254.

[14] Pretty, J., 2005, "Sustainability in Agriculture: Recent Progress and Emergent Challenges," Issues Environ. Sci. Technol., 21, pp. 1-15.

[15] OECD, 2001, Environmental Indicators for Agriculture. Methods and Results., OECD, Paris.

[16] Amaro, P., 2005, As Organizações de Agricultores de Protecção Integrada e de Produção Integrada (1994 - 2004), ISA/Press, Lisboa.

[17] Carvalho, C. (Coord. ., 2003, Estudo de Avaliação Intercalar Do Plano de Desenvolvimento Rural de Portugal Continental. Relatório Final., Centro de Estudos e Formação Avançada em Gestão/Universidade de Évora, ERENA, Centro Interdisciplinar de Estudos Económicos, Lisboa.

[18] ProDeR, 2011, Síntese Da Distribuição Regional Da Execução Do ProDeR. Novembro 2011, Autoridade de Gestão do ProDer.
[19] Bandeiras, C. V., 2003, "A Política AgroAmbiental e as Novas Técnicas Agrícolas Em Portugal.," ISA/UTL, DEARS, Bragança, p. 17p.

[20] ProDeR, 2012, Relatório de Execução PRODER 2011., Programa de Desenvolvimento Rural, Ministério da Agricultura, do Mar, do Ambiente e do Ordenamento do Território, Lisboa.

[21] ProDeR, 2014, Relatório de Execução PRODER 2013, Programa de Desenvolvimento Rural, Ministério da Agricultura, do Mar, do Ambiente e do Ordenamento do Território, Lisboa.

[22] Rodrigo, I., and Bandeiras, C. V., 2003, As Medidas Agro-Ambientais. Protecção Integrada, Produção Integrada e Luta Química Aconselhada, Documento de Trabalho elaborado no âmbito do Projecto AGRO 13, ISA, Departamento de Economia Agrária e Sociologia Rural, Lisboa.

[23] DGADR, 2013, Entidades Reconhecidas., Direção Geral de Agricultura e Desenvolvimento Rural, Lisboa.

[24] MADRP, 2007, Vitivinicultura. Diagnóstico Sectorial., Gabinete de Planeamento e Políticas/Ministério da Agricultura, do Desenvolvimento Rural e das Pescas, Lisboa.

[25] Costa, C. A., 2016, Integrated Pest Management and the Sustainable Use of Pesticides. An Assessment of Environmental Performance and Market Potential. Annex 2. Pesticide Print Data Analysis., $\mathrm{PhD}$ thesis, Instituto Superior de Agronomia/Universidade de Lisboa, Lisboa.

[26] EU, 2012, Rural Development in the EU. Statistical and Economic Information Report 2012., European Commission.

[27] UNESCO, 2012, The International Standard Classification of Education 2011, United Nations Educational, Scientific and Cultural Organization, Institute for Statistics, Montreal.

[28] Blandford, D., 2010, Agricultural Policies and Rural Development - A Synthesis of Recent OECD Work., OECD, Paris.

[29] INE, 2010, Recenseamento Agrícola 2009. Dados Preliminares., INE destaque.

[30] FAO, 2013, 2000 World Census of Agriculture: Analysis and International Comparison of the Results (1996-2005)., Food and Agriculture Organization of the United Nations, Rome.

[31] Sattler, C., and Nagel, U. J., 2010, "Factors Affecting Farmers' Acceptance of Conservation Measures-A Case Study from North-Eastern Germany," Land Use Policy, 27(1), pp. 70-77.

[32] Waichman, V., Eve, E., and Celso da Silva Nina, N., 2007, "Do Farmers Understand the Information Displayed on Pesticide Product Labels? A Key 
Question to Reduce Pesticides Exposure and Risk of Poisoning in the Brazilian Amazon," Crop Prot., 26(4), pp. 576-583.

[33] INE, 2011, Recenseamento Agrícola 2009 - Análise Dos Principais Resultados, Instituto Nacional de Estatística, Lisboa.

[34] Torres, L., Carlos, C., Gonçalves, F., and Sousa, S., 2013, ImportâNcia Das Infra-Estruturas Ecológicas No Incremento Da Biodiversidade de Artrópodes Auxiliares Na Vinha, EcoVitis, Universidade de Trás-os-Montes e Alto Douro, Vila Real.

[35] Nunes, C., Teixeira, B., Carlos, C., Gonçalves, F., Martins, M., Crespí, A., Sousa, S., Torres, L., and Costa, C. A., 2015, "Biodiversidade Do Solo Em Vinhas Com e Sem Enrelvamento.," Rev. Ciênc. Agrár., 38(2), pp. 248-257.

[36] Larson, R., 2011, Implementability of AgroEnvironmental Targets in Denmark. Project Reporting. Baltic COMPASS (Comprehensive Policy Actions and Investments in Sustainable Solutions in Agriculture in the Baltic Sea Region). Work Package 6: Policy Adaptation and Governance., Stockholm Environment Institute (SEI), Stockholm.

[37] Straton, A., 2006, "A Complex Systems Approach to the Value of Ecological Resources," Ecol. Econ., 56(3), pp. 402-411. 